\title{
Collective Goods Neglected Goods
}


This page is intentionally left blank 


\section{Collective Goods \\ Neglected Goods}

Dealing with

Metbodological Failure

in the Social Sciences

\section{Herbert J. Kiesling}

Indiana University, Bloomington 


\section{Published by}

World Scientific Publishing Co. Pre. Ltd.

P O Box 128, Farrer Road, Singapore 912805

USA office: Suite 1B, 1060 Main Street, River Edge. NJ 07661

$U K$ office: 57 Shelton Street, Covent Garden, London WC2H 9HE

\section{British Library Cataloguing-in-Publication Data}

A catalogue record for this book is available from the British Library.

\section{COLLECTIVE GOODS, NEGLECTED GOODS: \\ Dealing with Methodological Faihure in the Social Sciences}

Copyright $\odot 2000$ by World Scientific Publishing Co. Pte. Ltd.

All rights reserved. This book, or parts thereof, may not be reproduced in any form or by any means, electronic or mechanical. including photocopying, recording or any information storage and retrieval system now known or to be invented, without written permission from the Publisher.

For photocopying of material in this volume, please pay a copying fee through the Copyright Clearance Center, Inc., 222 Rosewood Drive, Danvers, MA 01923. USA. In this case permission to photocopy is not required from the publisher.

ISBN $981-02-3846-0$

Printed in Singapore. 


\section{Preface}

I can remember clearly as a first year graduate student hearing Professor Herbert Fraser remark that economic methodology was that part of the discipline which became of interest to economists only in old age, the obvious implication, even to a neophyte student, being that economists in the prime parts of their careers - those actually doing the real work had better things to do with their time. I remember the twinkle in Herb Fraser's eye as he delivered this wisdom (sometimes within hearing of other faculty members who enjoyed the humor but did not demur), and while I did not even know what methodology was at the time, I remember thinking Fraser's remark was likely delivered tongue-in-cheek.

Tongue-in-cheek statements, as we all know, typically have a grain of truth in them, and later, when well into my own active career, I began to wonder. As a student of tax analysis and government policy making, I only gradually came to appreciate that statements similar to Fraser's remarks often betray more than just humor; they point to essential elements of what Dierdre McCloskey has termed the "rhetoric of economics," that is, how economists organize their persuasive efforts, where "persuasion" is considered in the broadest possible way. Persuasion depends importantly upon what persons choose to include in their investigations, or as McCloskey would put it, their "conversations."

I have come to believe, over the last half of my active career, that economics in particular, but other social sciences (and moral philosophy) in addition, have made major mistakes in the present century by omitting two important types of concerns from their "conversations," and that this has led to great social harm. (I speak of the mainstream, or dominant, traditions in the social sciences and moral philosophy; it would not do to talk of any academic discipline as a single entity.) First, social scientists 
have refused to include collective goods (or goals) within the domain of analytical concern (economics, psychology, moral philosophy), or have done so only selectively (sociology and political science.) Secondly, social scientists and moral philosophers, with few exceptions, have refused to collect data in depth concerning human subjective beliefs, opinions, and historical recollections. To an important extent the errors overlap, in that one reason always given for the non-inclusion of collective goods is the alleged difficulty of gathering data for collective good demands, data which would require quality interviewing techniques if it were gathered correctly.

These mistakes are methodological in nature, and so related to the realm of "rhetoric" discussed by McCloskey, although I must admit that thinking of them in terms of the McCloskey framework leaves me uneasy, for the simple reason that many economists seem to have misinterpreted McCloskey's rhetorical arguments as being "just" about persuasion with regard to arguments narrowly conceived (such as political stances), and so have not given them proper importance by incorrectly considering them "unscientific." Still, many of the points made by McCloskey in recent years (see especially the 1994 book) provide a context for my own criticisms. McCloskey speaks of how economists and psychologists "spurn whole classes of evidence," for example, and her criticism of logical positivism and empiricism helps greatly our understanding of the reasons for the neglect of the collective and subjective. ${ }^{1}$

In no way would it be correct to consider my pointing to these mistakes an original contribution on my part - there is nothing new under the sun - although perhaps I may be somewhat unique in pointing specifically to the consistency with which collective goals have been excluded outright in economics, psychology, and moral philosophy, and mishandled elsewhere. And while any number of writers have pointed to the absence of attempts to gather subjective data in one discipline or the other, I am not aware of any who have pointed to the consistency in which attempts to gather quality subjective data have been avoided in all the social sciences, as well as in moral philosophy, over the entire

'McCloskey (1994: 101). To the extent that McCloskey is part of a postmodemist movement that holds that "anything goes," as alleged by Blaug, 1 would however be in disagreement with Blaug (1998a: 29). 
twentieth century. The twentieth century has been the century of specialization, and persons concentrating on one discipline only (more normally, a small slice of a discipline) have failed to notice the immensity and sweeping nature of these problems.

I can also note with satisfaction that, in recent times, there is a large and increasing number of serious academic writers who are noticing and writing about substantial portions of these issues. Any number of writers have pointed to the unfortunate split between the study of marketplace efficiency and moral concerns in economics, as well as the excessive narrowness in viewpoint of mainstream economists more generally. Perhaps the most noteworthy of these has been Amartya Sen. Others that readily come to mind include Mark Blaug, Allen Buchanan, Amitai Etzioni, Robert Frank, Robert Goldfarb, William Griffith, John Maloney, Dierdre McCloskey, Howard Margolis, Patrick Larkey, Wassily Leontif, Patrick O'Sullivan, Deborah Redman, and Lionel Robbins. Writers adopting critical stances in other disciplines besides economics include Elizabeth Anderson, Joseph Bessette, John Glass, John Goldthorpe, Rollo Handy, Seymour Sarason, Barry Schwartz, M. Brewster Smith, Sybe Terwee, James Wertsch, and Frederick Werz. There are many others. One could undoubtedly add most feminist social scientists, as well as many young methodologists. In the late 1950s, the fine novelist, C.P. Snow, pointed out the seriousness of a problem of "two cultures" among the intelligentsia, where "Scientists" and non-scientists "had almost ceased to communicate at all, who in intellectual, moral, and psychological climate had so little in common that instead of going from Burlington House or South. Kensington to Chelsea, one might have crossed an ocean." 2 Mancur Olson, the important early writer about collective goods, has recently argued that the study of efficiency issues is not nearly enough to explain the success or failure of newly developing nations. The magazine writer John Cassidy pointed out how the recent winner of the Nobel prize in economics, William Vickrey, quickly dismissed his prize-winning 1961 paper as "one of my digressions into abstract economics," going on to say, "At best, it's of minor significance in terms of human welfare."3 Newspaper reporters in articles covering annual meetings of the American Economic Association

2Snow [1971 (1959): 14].

'Cassidy (1996: 51). 
often comment on how arcane and unrelated to the real world are many of the sessions. There are numerous critics in other disciplines too, as further discussed in Chapter 4.

Due to the pervasive nature of the two methodological errors which provide the subject matter of the book, the narrative stretches over a sizable range of subject matter, and so the book is meant to be of interest to a broad class of readers: those in the social sciences and moral philosophy, historians, journalists, the law, interested persons in the general public, and perhaps even some political leaders. I have tried to make the discussion in the book accessible to all these readers. Perhaps with the natural bias typically possessed by authors, I consider the message of the book to be of great enough social importance to merit a fairly broad level of interest and concern.

Again, I must acknowledge my great debt of gratitude to my colleague, H. Scott Gordon. I first began to be interested in broader social concerns many years ago when Scott gave a lecture in one of my graduate courses on the subject of justice and equality. Professor Gordon is wiser than I on many of the issues discussed below, and his comments have been a constant source of help over the years. I should point out, however, that Scott and I are not always in agreement, and specific instances of this, in particular with respect to the place of subjective data and of ethical naturalism, will appear in the pages below. Others who have been helpful in various ways have included Robert Bish, Keith Caldwell, Christopher Clague, Dean Dudley, Allen Grimshaw, Francis Feddersen, Helen Hollingsworth, John Kennedy, Pat Larkey, Tom Lyon, Michael McGinnis, Roger Noll, Ron Oakerson, Dong Mayhard, Mancur Olson, Julie Pedroni, Claire Robertson, Bertina Rudman, Karl Schuessler, Eugene Steuerle, Dennis Young, and James Wertsch. I owe a profound debt for editorial help I received from Bob and Marcia Kern, who proved once and for all that friendship need not stand in the way of perceptive and incisive editing, and also to Donna Snow Robinson, who edited the entire manuscript. I also owe a deep debt to my three in-depth interview respondents who, unfortunately, must remain anonymous.

My greatest debt over the years devoted to the writing of this and my previous book is due for the support given me by my wife Iris and two children, Scott and Stephanie, all three of whom have been wonderfully perceptive about many of the issues discussed in the book, and from 
whose comments I have benefited a great deal. Scott is an academic linguist in his own right, and so has been able to give me a number of useful comments relating to his field, especially for the material in Chapter 7. I would like to dedicate this book to them.

And finally, the psychologist Seymour Sarason dedicated his 1981 book, Psychology Misdirected, as follows: "To John Dewey, Prophet with Honor," thus capturing a bit of the admiration I also feel for one of the truly towering intellectual presences of the modern era. Perhaps I flatter myself to think that this book may have met with his approval. 
This page is intentionally left blank 


\section{Contents}

Preface v v

Introduction 1

Part 1. Methodological Failures 27

Chapter 1. Collective Goods and Economic Science 29

Chapter 2. Rationality and Motivation 56

$\begin{array}{ll}\text { Chapter 3. Emotion } & 78\end{array}$

Chapter 4. The "Other" Social Sciences 99

Chapter 5. The Evaluation of Collective Goods Delivery 127

Part 2. New Directions 151

Chapter 6. What Can Be Done? 153

Chapter 7. Exploring the Human Subject 190

Postscript $\quad 225$

References 233

Subject Index 251

Author Index 259 